\title{
Recycling Spent Lead-Acid Batteries into Lead Halide for Resource Purification and Multifunctional Perovskite Diodes
}

Jiong Li, ${ }^{1 \#}$ Chenghao Duan, ${ }^{1 \#}$ Ligang Yuan, ${ }^{1}$ Zidan Liu, ${ }^{1}$ Hepeng Zhu, ${ }^{1}$ Jianwei Ren, ${ }^{2}$ Keyou Yan ${ }^{1 *}$

1. School of Environment and Energy, Guangdong Provincial Key Laboratory of Solid Wastes Pollution Control and Recycling, South China University of Technology, Guangzhou 510000, China.

2. Department of Mechanical Engineering Science, University of Johannesburg, Cnr Kingsway and University Roads, Auckland Park, 2092, Johannesburg, South Africa.

E-mail : kyyan@scut.edu.cn 


\section{catalogue}

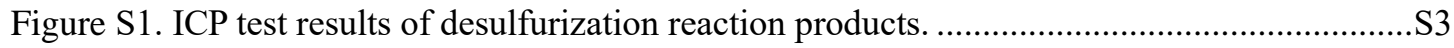

Figure S2. Yellow lead oxide powder obtained by calcination. ................................................... 4

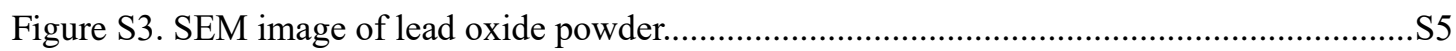

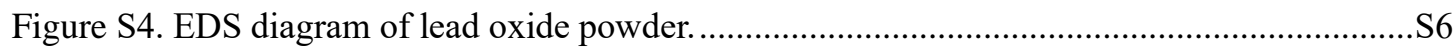

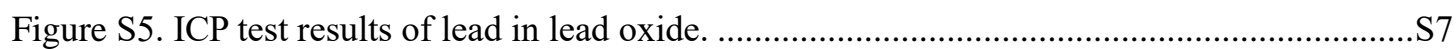

Figure S6. High-purity $\mathrm{PbI}_{2}$ powder extracted from spent lead-acid batteries................................S8

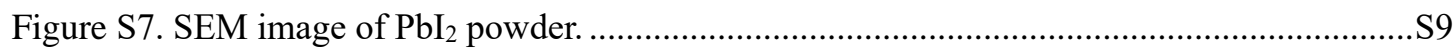

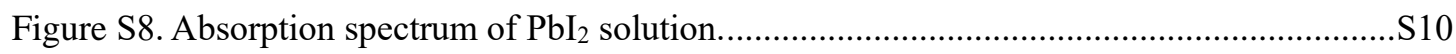

Figure S9. High-purity $\mathrm{PbBr}_{2}$ powder extracted from spent lead-acid batteries............................S11

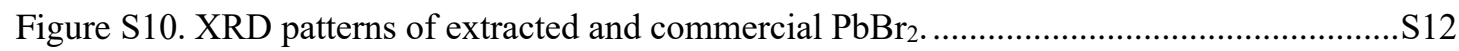

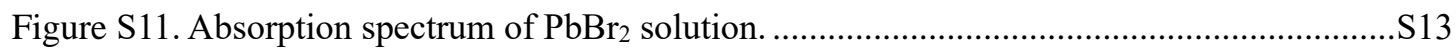

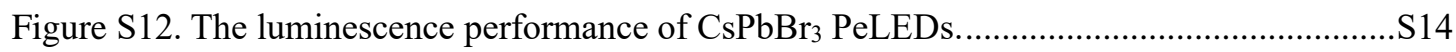

Figure S13. EQE diagram of perovskite light-emitting diode fabricated from recycled lead iodide

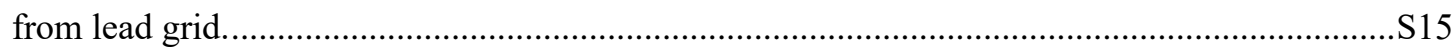

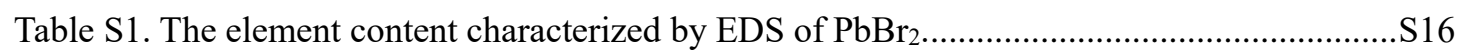

Table S2. The material consumption of $100 \mathrm{~g}$ lead grid.............................................................. 17

Table S3. The cost of each component in the lead-acid battery recycling process. ......................S18

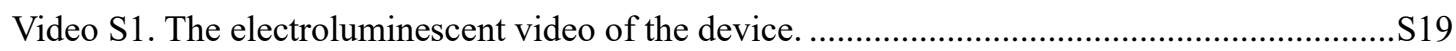

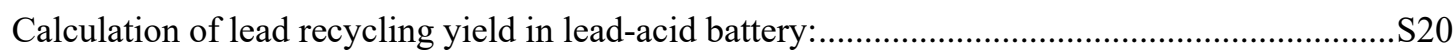

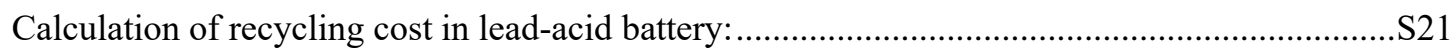

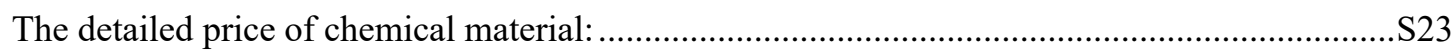




\begin{tabular}{|c|c|c|c|c|}
\hline \multirow[t]{2}{*}{$\begin{array}{l}\text { Sample } \\
\text { Analysis Date }\end{array}$} & \multicolumn{2}{|c|}{$\begin{array}{l}\text { Sample-LJ-1 } \\
\text { 1/11/2021 5:17:34 PM }\end{array}$} & \multicolumn{2}{|c|}{$\begin{array}{l}0.0133 \\
50\end{array}$} \\
\hline & & $\begin{array}{r}\text { Sb } 206.833 \\
\{463\} \text { (Axial) }\end{array}$ & $\begin{array}{r}\mathrm{Pb} 220.353 \\
\{453\} \text { (Axial) }\end{array}$ & $\begin{array}{r}\text { Fe } 259.940 \\
\{130\} \text { (Axial) }\end{array}$ \\
\hline \multicolumn{2}{|c|}{ Concentration average } & $121.897 \mathrm{mg} / \mathrm{l}$ & $437,008.054 \mathrm{mg} / \mathrm{l}$ & $1,393.937 \mathrm{mg} / \mathrm{l}$ \\
\hline \multicolumn{2}{|c|}{ Concentration RSD } & $14.8 \%$ & $0.1 \%$ & $21.5 \%$ \\
\hline
\end{tabular}

Figure S1. ICP test results of desulfurization reaction products. 


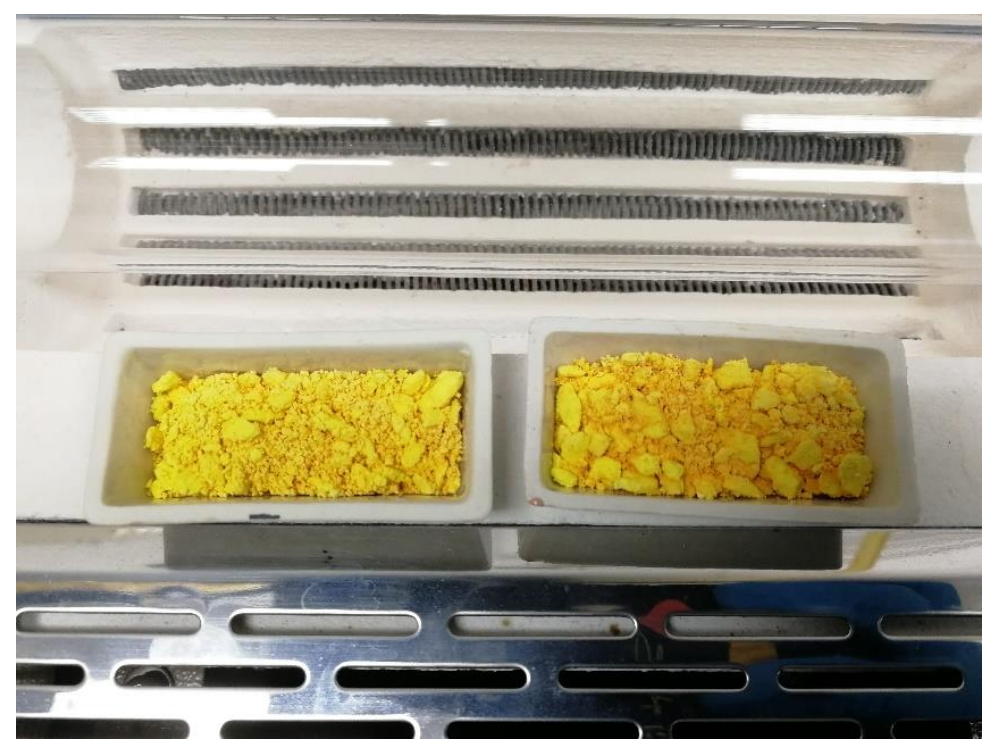

Figure S2. Yellow lead oxide powder obtained by calcination. 


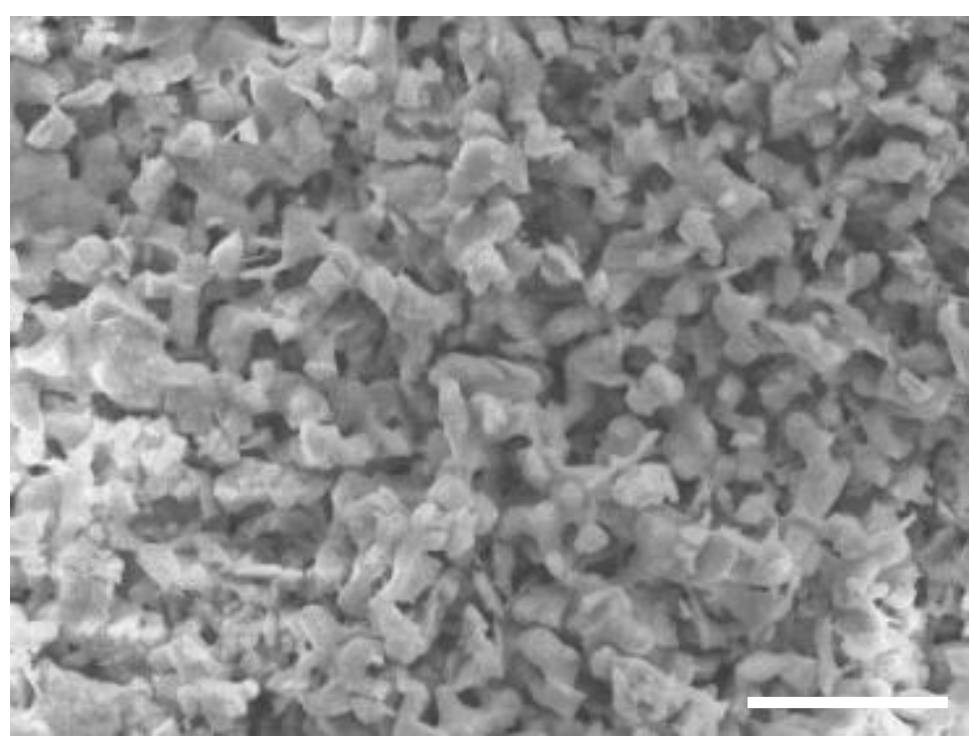

Figure S3. SEM image of lead oxide powder. 


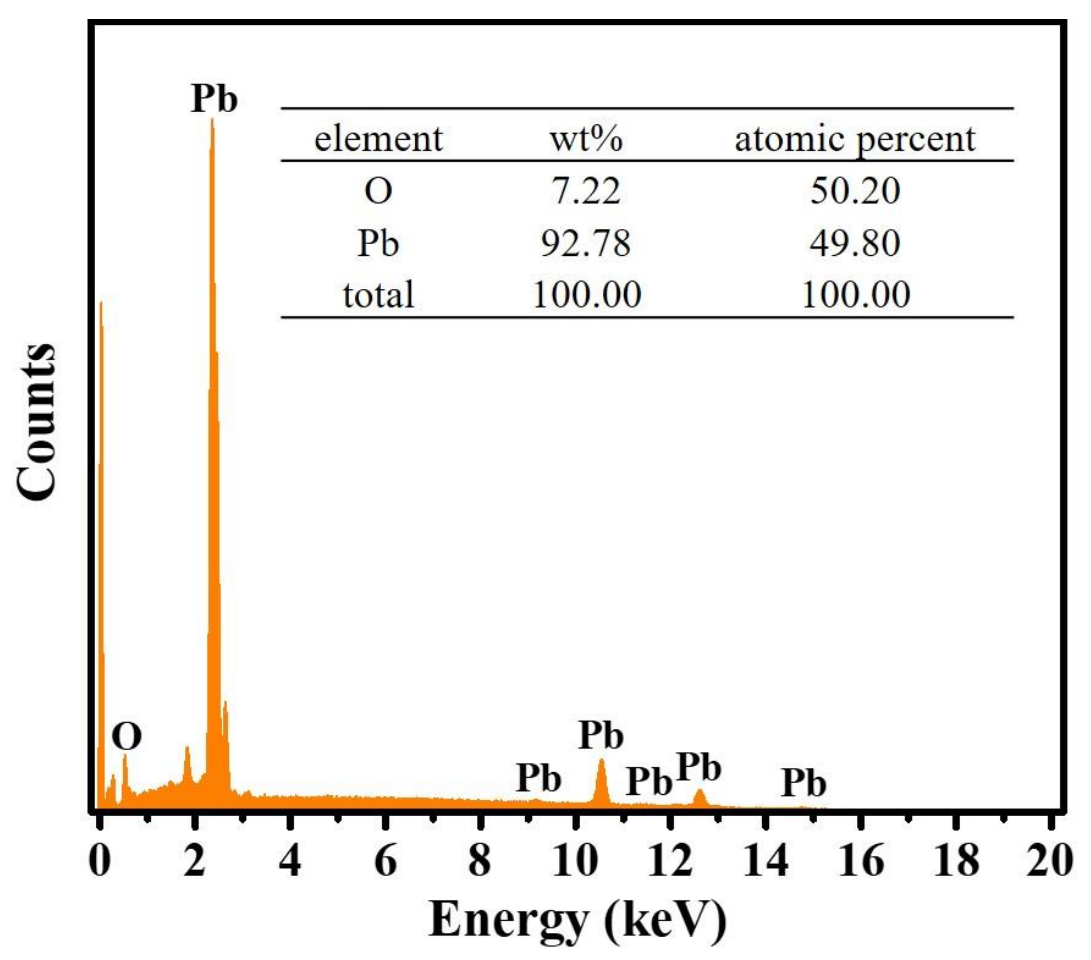

Figure S4. EDS diagram of lead oxide powder. 


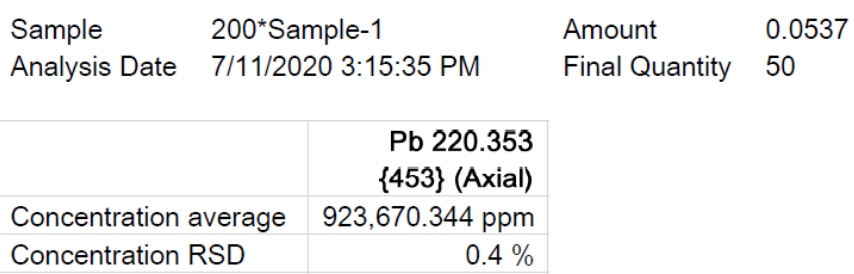

Figure S5. ICP test results of lead in lead oxide. 


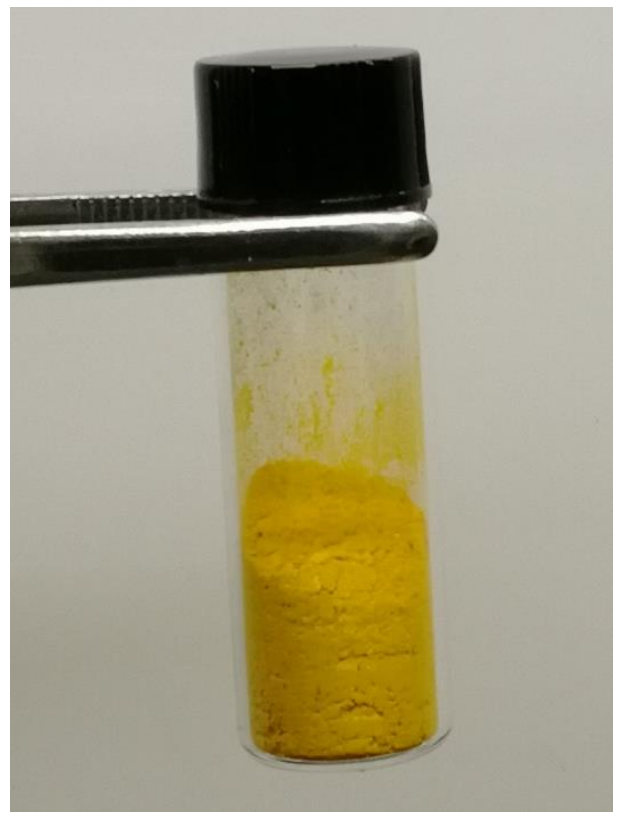

Figure S6. High-purity $\mathrm{PbI}_{2}$ powder extracted from spent lead-acid batteries. 


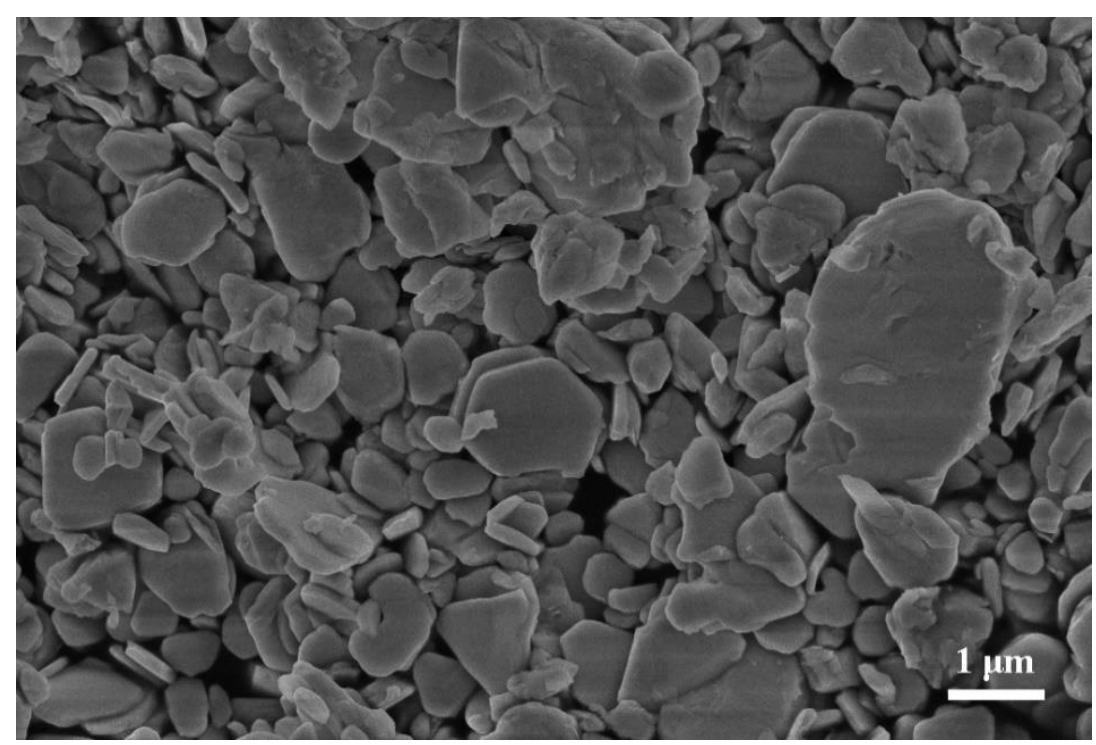

Figure S7. SEM image of $\mathrm{PbI}_{2}$ powder. 


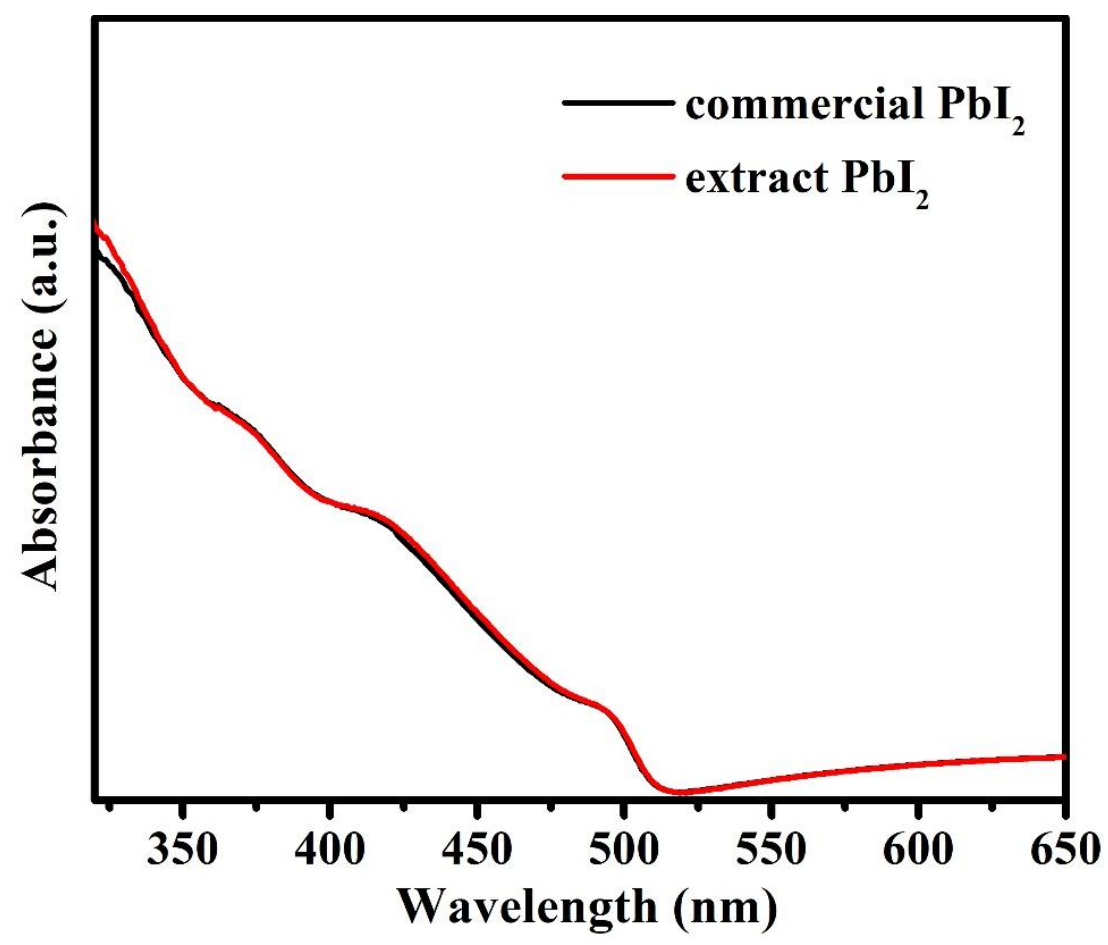

Figure S8. Absorption spectrum of $\mathrm{PbI}_{2}$ solution. 


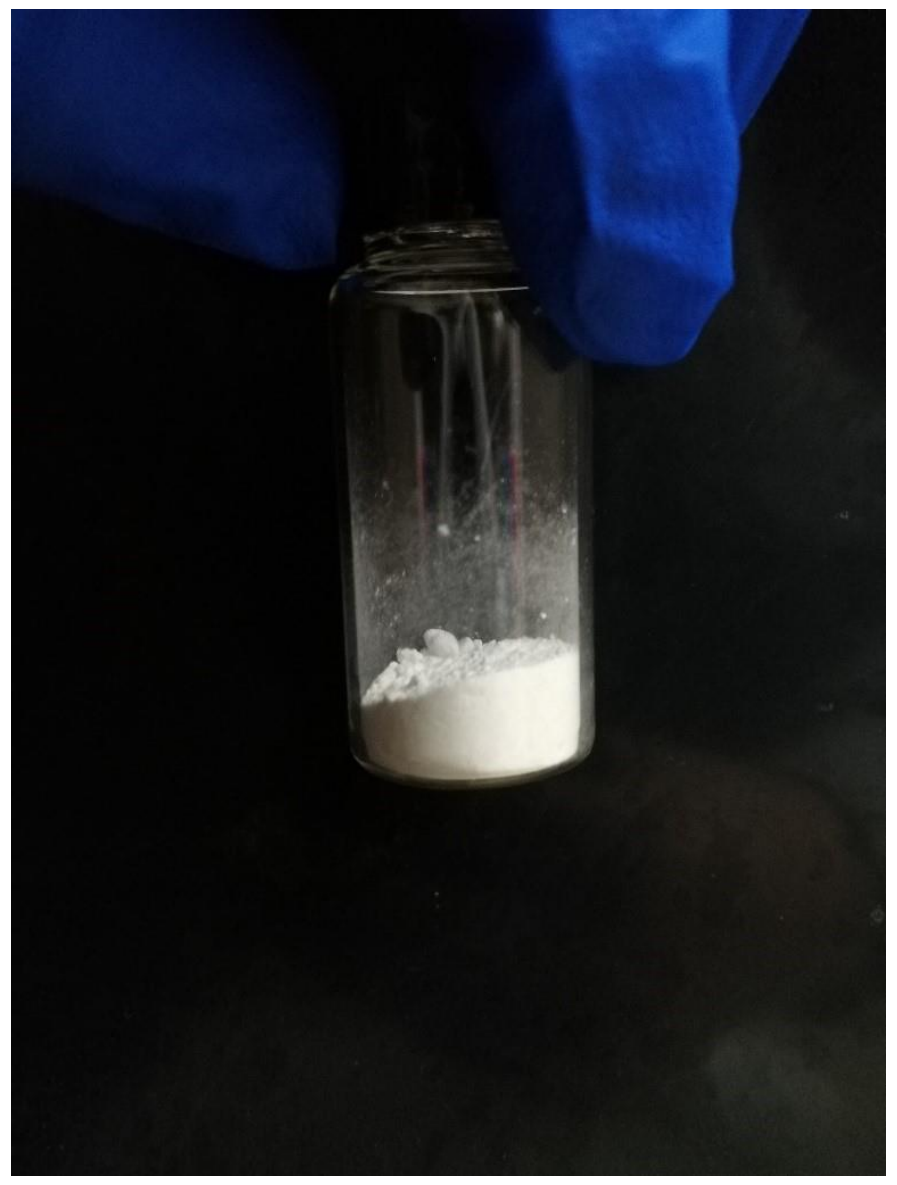

Figure S9. High-purity $\mathrm{PbBr}_{2}$ powder extracted from spent lead-acid batteries. 


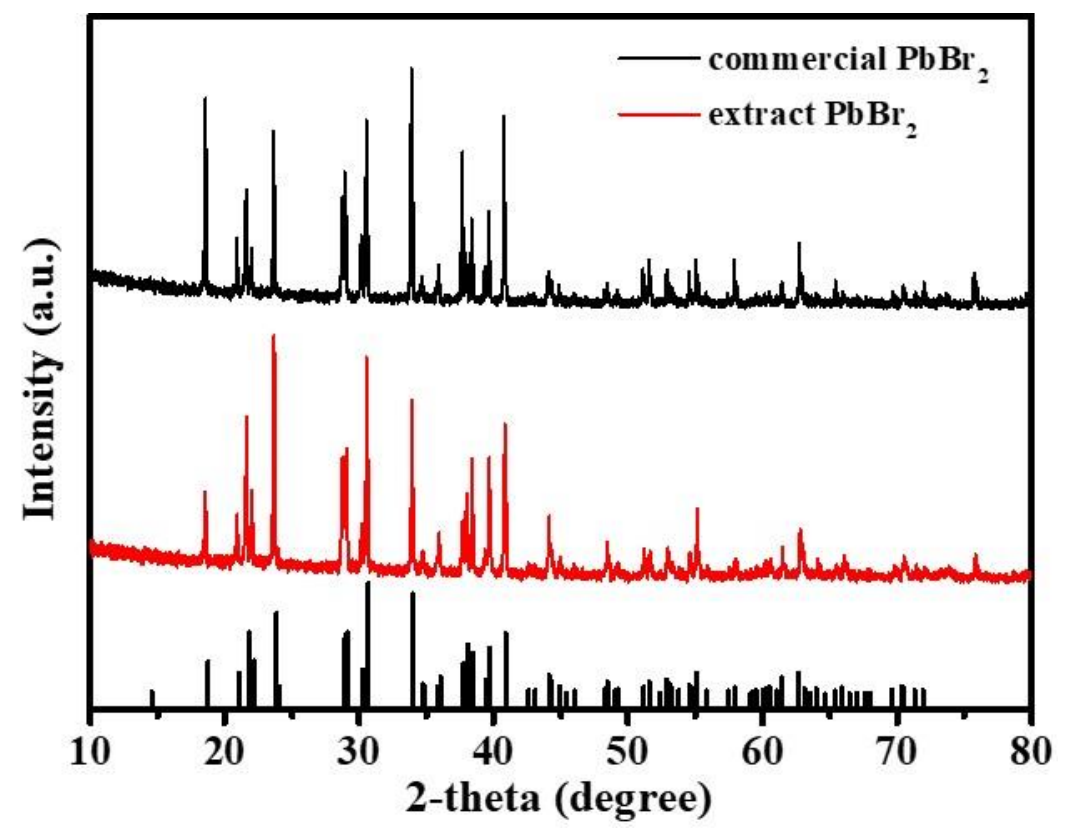

Figure S10. XRD patterns of extracted and commercial $\mathrm{PbBr}_{2}$. 


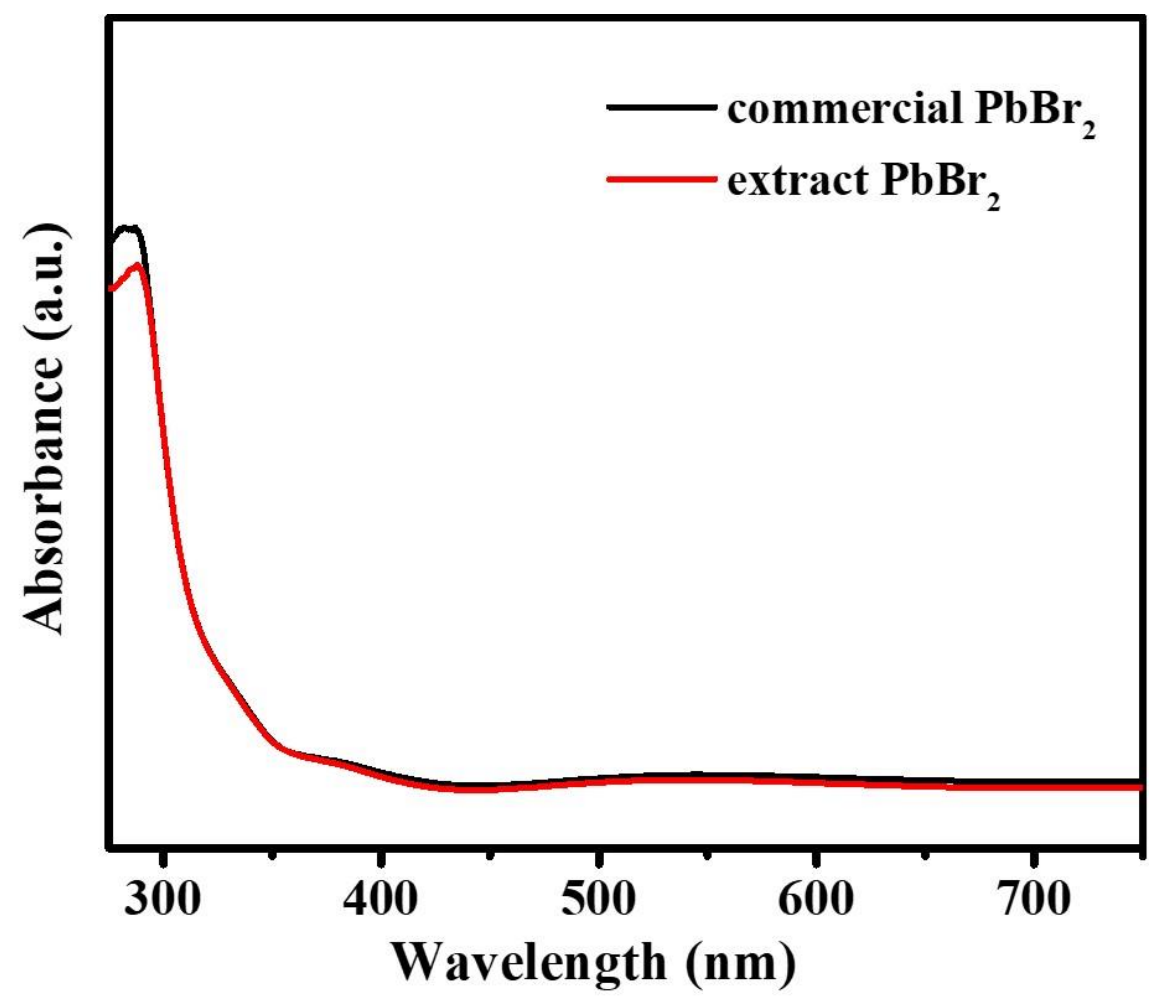

Figure S11. Absorption spectrum of $\mathrm{PbBr}_{2}$ solution. 


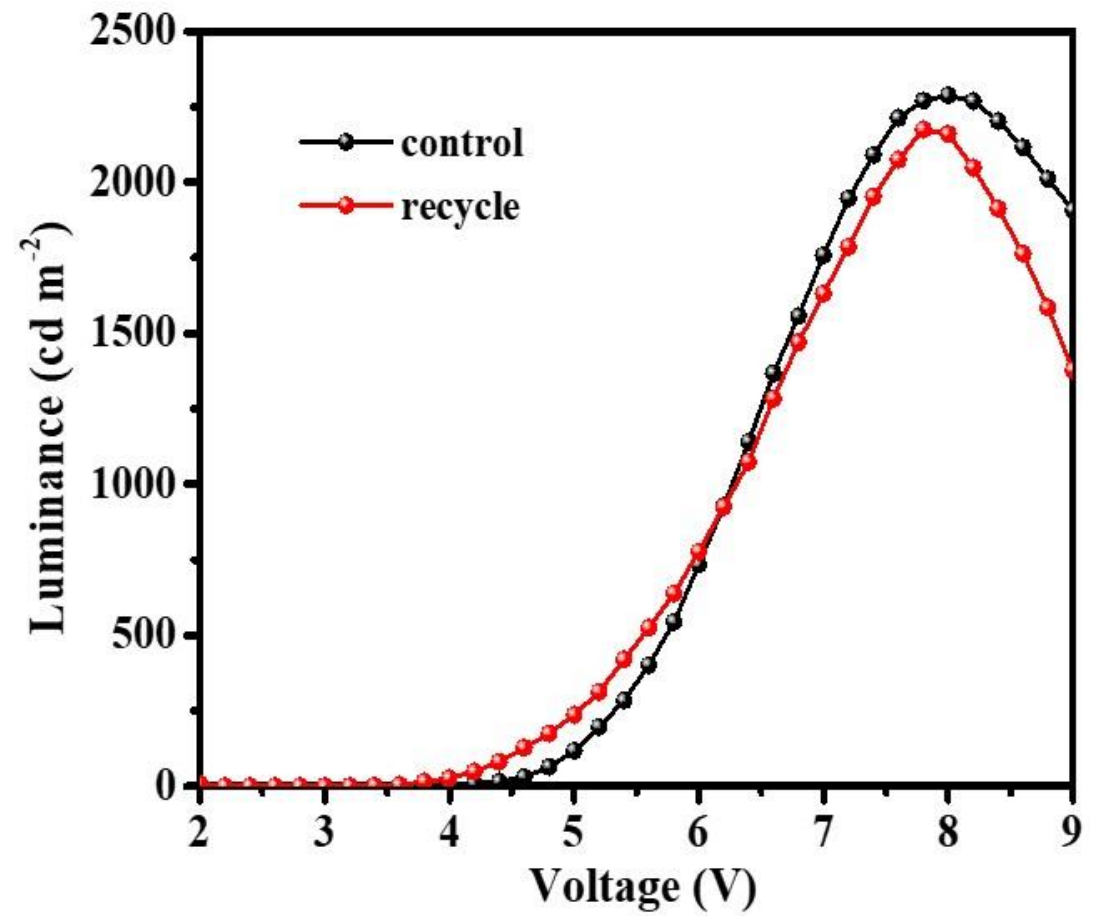

Figure S12. The luminescence performance of $\mathrm{CsPbBr}_{3} \mathrm{PeLEDs}_{\text {. }}$ 


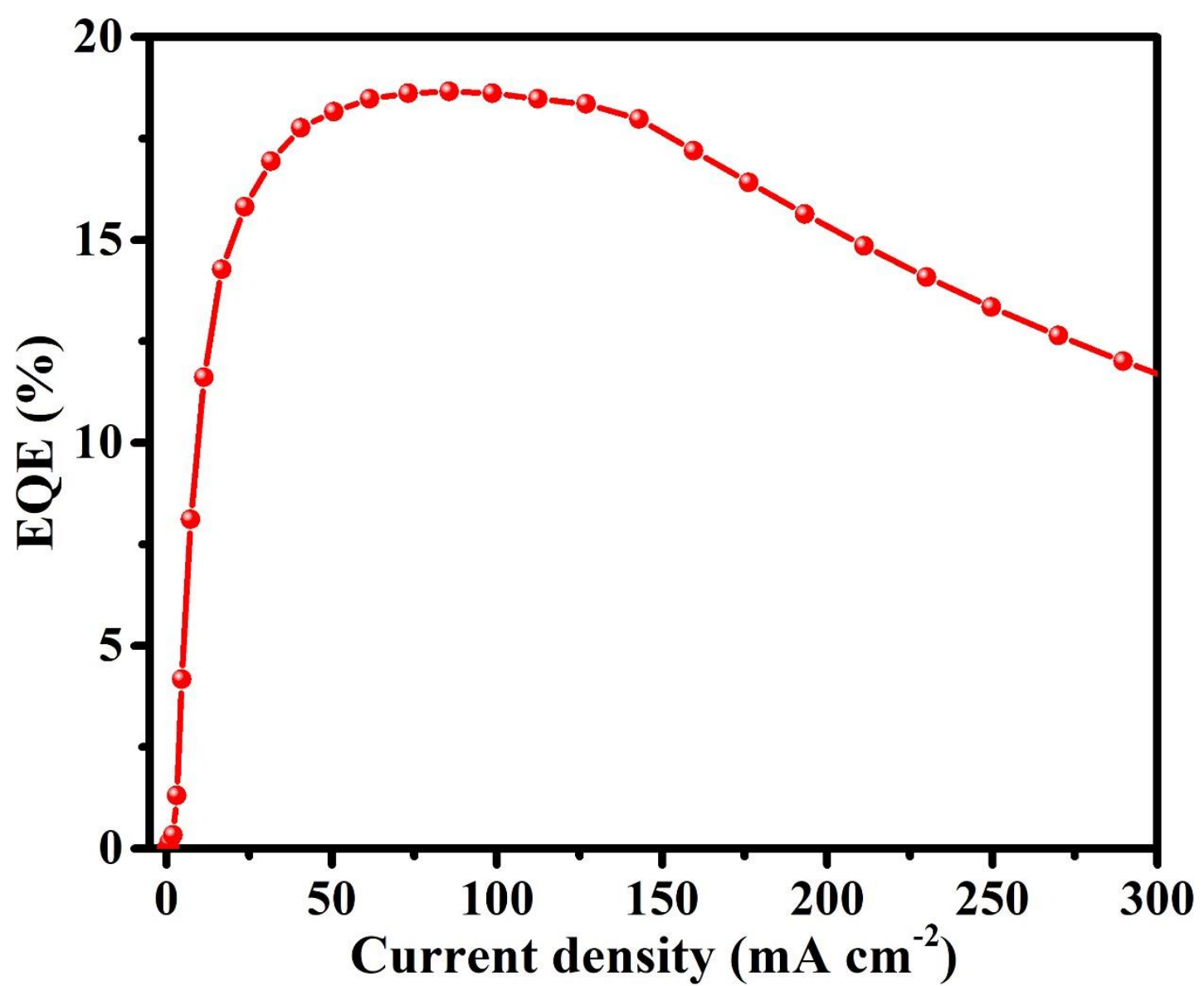

Figure S13. EQE diagram of perovskite light-emitting diode fabricated from recycled lead iodide from lead grid. 
Table S1. The element content characterized by EDS of $\mathrm{PbBr}_{2}$.

\begin{tabular}{ccc}
\hline element & $\mathbf{w t} \%$ & atomic percent \\
\hline $\mathrm{Br}$ & 42.04 & 65.29 \\
$\mathrm{~Pb}$ & 57.96 & 34.71 \\
total & 100.00 & 100.00 \\
\hline
\end{tabular}


Table S2. The material consumption of $100 \mathrm{~g}$ lead grid.

\begin{tabular}{cccccc}
\hline Materials & \multicolumn{2}{c}{ Price } & Dosage & \multicolumn{2}{c}{ Cost (\$) } \\
\hline $\begin{array}{c}\text { Concentrated } \\
\text { HNO }\end{array}$ & Laboratory & Industry & & Laboratory & Industry \\
HI & $50 \$ / \mathrm{L}$ & $0.21 \$ / \mathrm{L}$ & $0.085 \mathrm{~L}$ & 4.3 & 0.0179 \\
DMF & $206 \$ / \mathrm{L}$ & $1.60 \$ / \mathrm{L}$ & $0.115 \mathrm{~L}$ & 23.7 & 0.1840 \\
Lead Grid & $188 \$ / \mathrm{L}$ & $3.71 \$ / \mathrm{L}$ & $0.05 \mathrm{~L}$ & 9.4 & 0.1855 \\
Human Cost & & & & 0.3 & 0.3000 \\
$\begin{array}{c}\text { Others (Waste } \\
\text { disposal ...) }\end{array}$ & & & & 47.1 & 0.3437 \\
Total & & & & 9.4 & 0.1146 \\
\hline
\end{tabular}


Table S3. The cost of each component in the lead-acid battery recycling process.

\begin{tabular}{|c|c|c|c|c|}
\hline & & Lead Paste & Lead Grid & Electrode Plate \\
\hline \multicolumn{2}{|c|}{ Initial Quality (g) } & 100 & 100 & 100 \\
\hline \multicolumn{2}{|c|}{ Recycled $\mathrm{PbI}_{2}$ (g) } & 144.3 & 213.1 & 164.0 \\
\hline \multicolumn{2}{|c|}{ Recycling Yield (\%) } & 91.6 & 95.7 & 93.1 \\
\hline \multirow{2}{*}{ Cost (\$) } & laboratory & 87.0 & 94.2 & 89.1 \\
\hline & industry & 1.0610 & 1.1457 & 1.0852 \\
\hline \multirow{2}{*}{ Price $(\$ / g)$} & laboratory & 0.6029 & 0.4420 & 0.5433 \\
\hline & industry & 0.0074 & 0.0054 & 0.0066 \\
\hline
\end{tabular}

Note: According to our weighing, the electrode plate contains $71.4 \mathrm{wt} \%$ lead paste and $28.6 \mathrm{wt} \%$ lead grid. 


$$
D
$$

electroluminescer

Video S1. The electroluminescent video of the device. 


\section{Calculation of lead recycling yield in lead-acid battery:}

In lead paste, it mainly contains $50 \mathrm{wt} \% \mathrm{PbSO}_{4}, 28 \mathrm{wt} \% \mathrm{PbO}_{2}, 9 \mathrm{wt} \% \mathrm{PbO}, 4 \mathrm{wt} \%$ metallic $\mathrm{Pb}$, and the total amount of $\mathrm{Pb}$ element is $70.76 \mathrm{wt} \%$. Our experimental weight of lead paste was $21.6098 \mathrm{~g}$.

$$
\begin{gathered}
\mathrm{PbSO}_{4}+\left(\mathrm{NH}_{4}\right)_{2} \mathrm{CO}_{3} \rightarrow \mathrm{PbCO}_{3}+\left(\mathrm{NH}_{4}\right)_{2} \mathrm{SO}_{4} \\
\mathrm{PbCO}_{3} \stackrel{600^{\circ} \mathrm{C}}{\longrightarrow} \mathrm{PbO}+\mathrm{CO}_{2} \\
\mathrm{PbO}_{2} \stackrel{600^{\circ} \mathrm{C}}{\longrightarrow} \mathrm{PbO}+1 / 2 \mathrm{O}_{2} \\
\mathrm{~Pb}+1 / 2 \mathrm{O}_{2} \stackrel{600^{\circ} \mathrm{C}}{\longrightarrow} \mathrm{PbO} ; \mathrm{Pb}+\mathrm{PbO}_{2} \stackrel{600^{\circ} \mathrm{C}}{\longrightarrow} \mathrm{PbO}
\end{gathered}
$$

First, an excess of $\left(\mathrm{NH}_{4}\right)_{2} \mathrm{CO}_{3}$ solution is added to the ground lead paste. The $\mathrm{PbSO}_{4}$ of lead paste will react with $\left(\mathrm{NH}_{4}\right)_{2} \mathrm{CO}_{3}$ to form $\mathrm{PbCO}_{3}$ and $\left(\mathrm{NH}_{4}\right)_{2} \mathrm{SO}_{4}$. Then, the washed precipitate is calcined in a tubular furnace at $600^{\circ} \mathrm{C}$ to obtain the $\mathrm{PbO}$ product. After the wet-fire process, according to the law of mass conservation, the theoretical mass of $\mathrm{PbO}$ should be $16.4730 \mathrm{~g}$, while the actual mass of $\mathrm{PbO}$ is $15.4817 \mathrm{~g}$. After characterization, we know that the purity of $\mathrm{PbO}$ is $99.5 \%$.

$$
\begin{aligned}
& \mathrm{PbO}+2 \mathrm{HNO}_{3} \rightarrow \mathrm{Pb}\left(\mathrm{NO}_{3}\right)_{2}+\mathrm{H}_{2} \mathrm{O} \\
& \mathrm{Pb}\left(\mathrm{NO}_{3}\right)_{2}+2 \mathrm{HI} \rightarrow \mathrm{PbI}_{2}+2 \mathrm{HNO}_{3}
\end{aligned}
$$

$\mathrm{PbO}$ reacts with $\mathrm{HNO}_{3}$ and $\mathrm{HI}$ step by step, and $31.1930 \mathrm{~g}$ of $\mathrm{PbI}_{2}$ is finally obtained.

According to the conservation of lead mass, we obtained the calculation formula:

Yield $(\%)=\frac{m_{\mathrm{PbI}_{2}} \times \frac{M_{P b}}{M_{\mathrm{PbI}_{2}}}}{m_{\text {lead } \text { in lead paste }}} \times 100 \%=\frac{31.1930 \mathrm{~g} \times \frac{207}{461}}{21.6098 \mathrm{~g} \times 70.76 \%} \times 100 \%=91.6 \%$

Therefore, the recycling yield of lead iodide from lead paste is $91.6 \%$. The calculation method of lead bromide is the same as above. Similarly, we reacted the remaining $8.6373 \mathrm{~g}$ lead grid with dilute nitric acid and hydroiodic acid to obtain $18.4086 \mathrm{~g}$ of lead iodide with a recycling yield of $95.7 \%$.

In summary, in a $30.2471 \mathrm{~g}$ electrode plate, the lead element content is $23.9284 \mathrm{~g}$, and we obtained $49.6016 \mathrm{~g}$ recycled lead iodide. The total recycling yield of whole electrode plate is calculated to be $93.1 \%$. 


\section{Calculation of recycling cost in lead-acid battery:}

In lead paste, it mainly contains $50 \mathrm{wt} \% \mathrm{PbSO}_{4}, 28 \mathrm{wt} \% \mathrm{PbO}_{2}, 9 \mathrm{wt} \% \mathrm{PbO}, 4 \mathrm{wt} \%$ metallic $\mathrm{Pb}$, and the total amount of $\mathrm{Pb}$ element is $70.76 \mathrm{wt} \%$. We calculate the recycling cost in terms of $100 \mathrm{~g}$ of lead paste.

$$
\mathrm{PbSO}_{4}+\left(\mathrm{NH}_{4}\right)_{2} \mathrm{CO}_{3} \rightarrow \mathrm{PbCO}_{3}+\left(\mathrm{NH}_{4}\right)_{2} \mathrm{SO}_{4}
$$

The double $\left(\mathrm{NH}_{4}\right)_{2} \mathrm{CO}_{3}$ solution was added to the ground lead paste and reacted with $\mathrm{PbSO}_{4}$ to produce $\mathrm{PbCO}_{3}$ and $\left(\mathrm{NH}_{4}\right)_{2} \mathrm{SO}_{4}$ to achieve the purpose of complete desulfurization. So, the amount of $\left(\mathrm{NH}_{4}\right)_{2} \mathrm{CO}_{3}$ required for $100 \mathrm{~g}$ of lead paste is approximately $0.033 \mathrm{~kg}$.

$$
\mathrm{PbO}+2 \mathrm{HNO}_{3} \rightarrow \mathrm{Pb}\left(\mathrm{NO}_{3}\right)_{2}+\mathrm{H}_{2} \mathrm{O}
$$

$21.6098 \mathrm{~g}$ of lead paste could yield $15.4817 \mathrm{~g}$ of $\mathrm{PbO}$. According to the chemical equation, $8.7489 \mathrm{~g}$ of pure $\mathrm{HNO}_{3}$ is required to completely convert $\mathrm{PbO}$ to $\mathrm{Pb}\left(\mathrm{NO}_{3}\right)_{2}$. Furthermore, the mass of pure $\mathrm{HNO}_{3}$ required for $100 \mathrm{~g}$ lead paste is $40.4858 \mathrm{~g}$. In our experiment, $68 \mathrm{wt} \%$ concentrated $\mathrm{HNO}_{3}$ was diluted and then reacted with $\mathrm{PbO}$. Therefore, the calculation formula of the required amount of concentrated $\mathrm{HNO}_{3}$ is as follows:

$$
\begin{gathered}
V_{\text {thick } \mathrm{HNO}_{3}}(\mathrm{~L})=\frac{m_{\text {thick } \mathrm{HNO}_{3}}}{\rho_{\text {thick } \mathrm{HNO}_{3}}}=\frac{40.4858 \mathrm{~g} \div 68 \%}{1.4 \mathrm{~g} / \mathrm{cm}^{3}} \approx 0.04 \mathrm{~L} \\
\mathrm{~Pb}\left(\mathrm{NO}_{3}\right)_{2}+2 \mathrm{HI} \rightarrow \mathrm{PbI}_{2}+2 \mathrm{HNO}_{3}
\end{gathered}
$$

$\mathrm{PbI}_{2}$ is further obtained by the reaction of $\mathrm{Pb}\left(\mathrm{NO}_{3}\right)_{2}$ with hydroiodic acid. According to the chemical equation, $21.6098 \mathrm{~g}$ lead paste can produce $15.4817 \mathrm{~g} \mathrm{PbO}$, and the mass of $\mathrm{HI}$ needed to react $15.4817 \mathrm{~g} \mathrm{PbO}$ is $17.7630 \mathrm{~g}$. In comparison, the amount of $\mathrm{HI}$ required for $100 \mathrm{~g}$ lead paste was $82.1988 \mathrm{~g}$. In our experiment, $55 \mathrm{wt} \%$ hydroiodic acid was reacted with $\mathrm{Pb}\left(\mathrm{NO}_{3}\right)_{2}$. Therefore, the calculation formula of the required amount of hydroiodic acid is as follows:

$$
V_{\text {hydroiodic acid }}(L)=\frac{m_{\text {hydroiodic acid }}}{\rho_{\text {hydroiodic acid }}}=\frac{82.1988 \mathrm{~g} \div 55 \%}{1.96 \mathrm{~g} / \mathrm{cm}^{3}} \approx 0.076 \mathrm{~L}
$$

Therefore, in the process of recycling $100 \mathrm{~g}$ lead paste, the amount of $\left(\mathrm{NH}_{4}\right)_{2} \mathrm{CO}_{3}$, concentrated $\mathrm{HNO}_{3}$ and hydroiodic acid required are $0.033 \mathrm{~kg}, 0.04 \mathrm{~L}$ and $0.076 \mathrm{~L}$, respectively. Similarly, we calculate that $0.085 \mathrm{~L}$ of concentrated nitric acid and 0.115 
$\mathrm{L}$ of hydroiodic acid are needed to react $100 \mathrm{~g}$ of lead grid. In addition, human cost and other wastage cost during the experiment are also taken into account. Table S2 details the cost of each material we calculated based on the price.

In the end, we unified the recycling process of lead paste and lead grid and calculated the price of lead iodide recycled in laboratory and industry, respectively (Table S3). 


\section{The detailed price of chemical material:}

https://www.chem-mall.com/search/\%E7\%A2\%B3\%E9\%85\%B8\%E9\%93\%B5

\begin{tabular}{|l|l|l|l|l|l|l|}
\hline \begin{tabular}{|l|l|l|l|} 
Sigma- \\
Aldrich
\end{tabular} & $207861-1 \mathrm{KG}$ & $1 \mathrm{~kg}$ & 请咨询 & $\begin{array}{l}\text { 碳酸铵 } \\
\text { Ammium carbonate }\end{array}$ & $\begin{array}{l}1,568.94 \\
1,568.94\end{array}$ \\
\hline
\end{tabular}

https:/www.chem-mall.com/search/\%E7\%A1\%9D\%E9\%85\%B8

\begin{tabular}{|l|l|l|l|l|l|l|}
\hline $\begin{array}{l}\text { Sigma- } \\
\text { Aldrich }\end{array}$ & $30709-1 L$ & 11 & 请咨洵 & $\begin{array}{l}\text { 硝酸 } \\
\text { Nitric acid } \\
\text { 管制类型: 易制爆 }\end{array}$ & 347.74 & 347.71 \\
\hline
\end{tabular}

https://www.chem-mall.com/search/\%E6\%B0\%A2\%E7\%A2\%98\%E9\%85\%B8

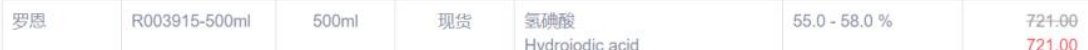

https://www.chem-mall.com/search/N-

N\%E4\%BA\%8C\%E7\%94\%B2\%E5\%9F\%BA\%E7\%94\%B2\%E9\%85\%B0\%E8\%83\%BA

\begin{tabular}{l|l|l|l|l|}
\hline Sigma-Aldrich & $227056-1 \mathrm{~L}$ & 11 & 请咨询 & $\mathrm{N}, \mathrm{N}-$ - 甲基甲酰胺 \\
\hline
\end{tabular}

\begin{tabular}{r|r}
$4,315.52$ \\
\hline
\end{tabular}

https://china.guidechem.com/trade/pdetail10870566.html

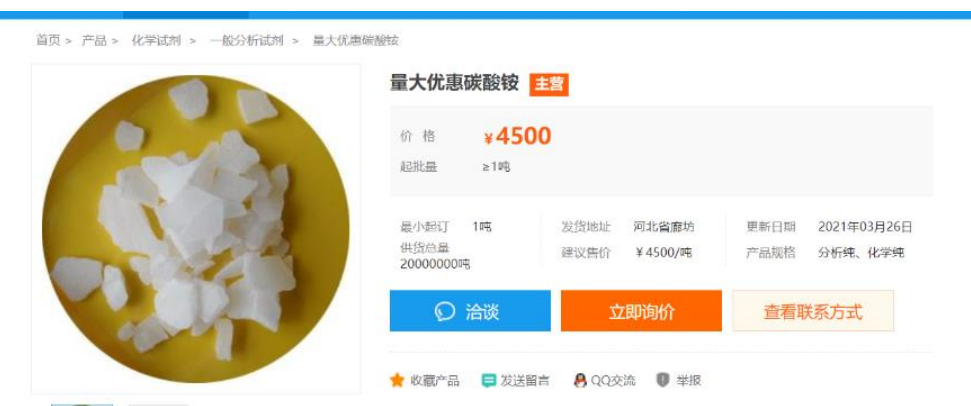

http://www.100ppi.com/vane/detail-723.html

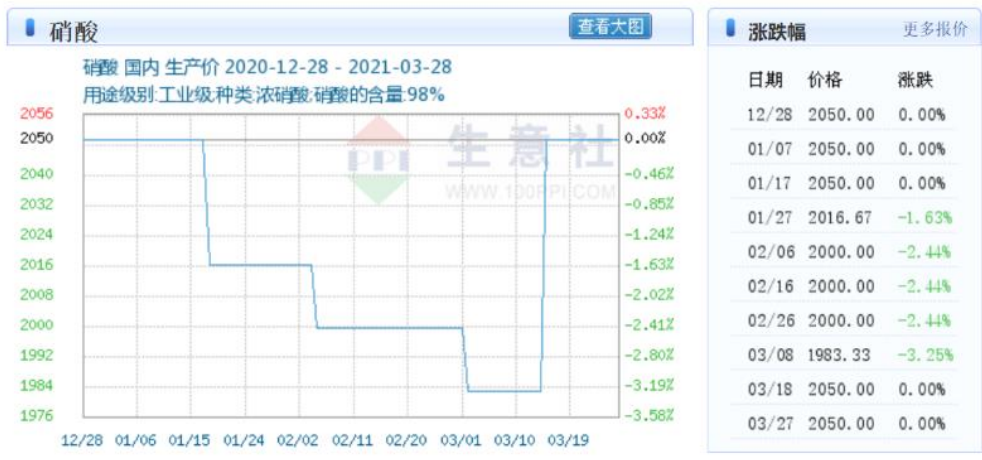

https://www.51 pla.com/html/sellinfo/317/31785569.htm 


\begin{tabular}{|c|c|c|c|}
\hline $\begin{array}{l}\text { 湖北露润德化工有限公司 } \\
\text { VIP7年 }\end{array}$ & 在结侚盃 & D洽谈 & 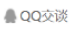 \\
\hline 联系电话：135-4501-7210 & \multicolumn{3}{|l|}{ 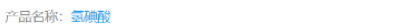 } \\
\hline 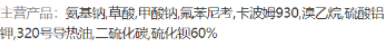 & \multicolumn{3}{|c|}{ 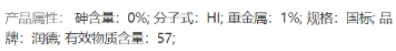 } \\
\hline 产品目录: $5000+$ & \multicolumn{3}{|l|}{ 態考价： $¥ 550 / 25$ 干克, } \\
\hline
\end{tabular}

https://detail.1688.com/offer/576008733764.html?spm=a261b.12436309.ul20190116.166.27821a

\section{d5jEwuQB}

长期供应 优级品二甲基甲酰胺工业级华鲁恒升国标DMF 可分装

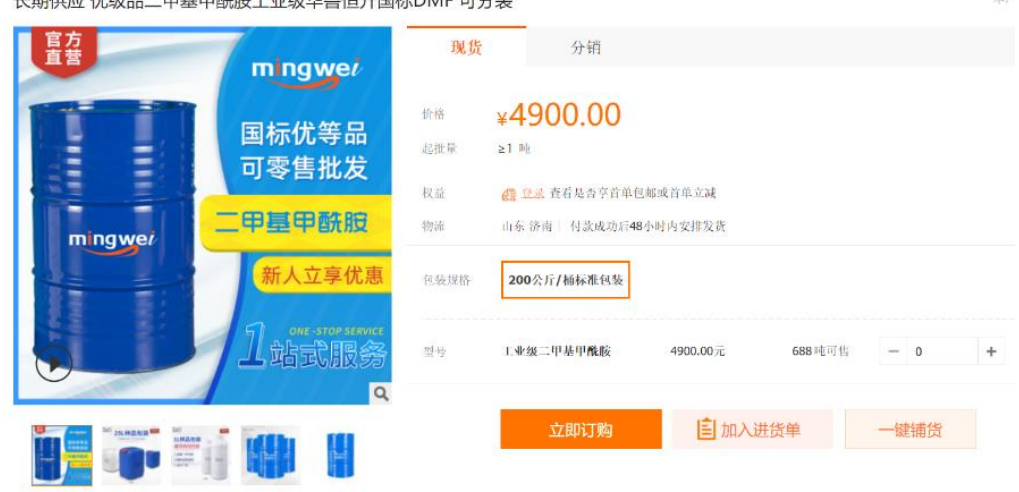

